\title{
Sociolinguistic Consciousness and Spoken English in Nigerian Tertiary Institutions
}

\author{
Ekpe, Mfon Brownson ${ }^{1}$ \\ ${ }^{1}$ Department of English \& Literary Studies, Redeemer's University, Mowe, Ogun State, Nigeria \\ Correspondence: Ekpe, Mfon Brownson, Department of English \& Literary Studies, Redeemer's University, \\ Mowe, Ogun State, Nigeria. E-mail: mfobrown@yahoo.com
}

Received: May 3, 2011 Accepted: May 24, 2012 Online Published: September 20, 2012

doi:10.5539/ells.v2n4p43 URL: http://dx.doi.org/10.5539/ells.v2n4p43

\begin{abstract}
The present status of English as a global language has led to the proliferation of many varieties of English all over the world, which according to Achebe (1965: 29) "is the price a world language...must pay in submission to many kinds of use". English as a global language has developed many varieties, which differ from the "standard" to the 'non standard'. Based on the extent of research thus far, there is no doubt that Nigerian English exists. To show its importance, it is made compulsory to every student in tertiary institution, no matter the student's field of study. Every student is expected to speak simple and correct English as it is the language of instruction and communication. On the function allocated to the use of English in tertiary institutions, everybody tries mastering the language both the written and the spoken forms. In our tertiary institutions, it is common to hear the students exhibit their proficiency in the language in relation to multidimensional space of level of education, ethnic background, discipline and style. In the teaching of English in our tertiary institutions, the argument is that the teachers of English have to be conscious of the sociolinguistic variables that may affect students' performance before embarking on effective teaching. We adopt 'Accommodation Theory' (1991) by Giles and Coupland as our "Theoretical Frame", while our analysis of "the selected Sociolinguistic variables are based on "Labovian Quantitative Method (1972: 181). Our analysis shows that for effective learning to take place, language instructors must be conscious of the social factors that may affect the learning and speaking of English in a second language situation.
\end{abstract}

Keywords: sociolinguistics, consciousness, variables, spoken English, Nigerian English

\section{Introduction}

This paper focuses on empirical investigation into the social factors that affect the different realizations of English sounds which give birth to the proliferation of different varieties of English in Nigerian Tertiary Institutions (ENTI). It is expected that a university undergraduate should be able to speak simple, correct and intelligible English that can be used to communicate across socio-cultural boundaries. This is the major reason the 'Use of English' is made compulsory in every tertiary institution in Nigeria, no matter the student's field of study. Despite this, many undergraduates still come out with different realization of forms different from the expected norms. Since this is more pronounced at the phonological than any other level of linguistic analysis, it gives us the impetus to investigate into the spoken English of students in our tertiary institutions.

In this investigation, there is basic assumption that the linguistic (phonological) variables in the speech forms of the students are caused by social variables such as social class, level of education, the student's discipline, ethnic background and style and for effective teaching and learning to take place language instructors have to be conscious of the sociolinguistic factors.

\section{Nature of Variation of English in Nigerian Tertiary Institutions}

The nature of variation in Nigerian English has attracted a lot of scholarly interest some of which include Banjo (1971, 1995, 2004) Jibril (1979, 1982), Akere (1975, 1976, 1978,1982,1990,2004), Eka (1985, 1993), Jowitt (1991), Bamgbose (1995, 2004), Adegbija (2002, 2004), Awonusi (2002, 2004), and Udofot (2000, 2004). Udofot, in her reclassification of varieties of Nigerian English, came out with three varieties: non- standard, standard and sophisticated English (2004: 109). The non-standard English is said to be spoken by primary and some secondary school students, some second year university undergraduates, National Diploma (ND), National 
Certificate of Education (NCE) certificate holders and primary school teachers. This variety is characterized by inability to make phonetic distinction, tendency to accent all syllables, irrelevant pausing and love for the falling tone.

The standard variety exponents are the third and final year undergraduates, university and college lectures, secondary school teachers of English and holders of Higher National Diploma (HND). The speakers of this variety have the ability to make some vital phonetic distinction, reasonably fluent speech, prominent syllables and unidirectional tones (the fall and the rise).

The sophisticated variety has as its exponents, university lecturers in English and Linguistics, graduates of English and Mass Communication and other courses in the Humanities. The features of this brand of English are the ability to make all phonetic distinctions, fluent speech, a few extra prominent syllables and flexible use of intonation in the mother tongue.

To the best of my knowledge, no work has been done in the area of "Sociolinguistic Consciousness and the Teaching of Oral English in Tertiary Institution" (OETI). It is this observation that provides justification for this work.

Like any other English speaking country, Nigeria has quite a number of varieties of English, (Awonusi 2004). Variation can be seen in different areas of language studies, however, we are concerned with phonological variations, which have given Nigerian English a peculiar characteristic distinct from the British English (BE) and other varieties of English spoken all over the world. Phonological variation is of interest to us because among all other criteria in demarcating Nigerian English, it is the criterion of phonology that is most outstanding. Phonology is preferable because the challenges associated with the learning and acquisition is more pronounced at the spoken than other levels of linguistic analysis, (Adetugbo 1993). The spoken forms are often replete with difficulties arising from regional dialects. Again, the problem of intelligibility and acceptability is more glaring at the spoken stratum. In Nigeria, elocution plays a vital role in terms of job opportunities, acceptance into social groups, admission into higher institutions, politics and commerce, Jowitt (1991). These are some of the sociological factors that make a study of this nature necessary. It is the basic motivation of this research, and we seek to establish among other things, this fact with some empirical evidence.

The present study is a contribution towards developing of spoken English in our tertiary institutions. It is specifically concerned with the investigation of some selected phonological and sociolinguistic variables from a production perspective. This study aims at,

* finding the correlation between the social class and the phonological variants.

$4 \quad$ determining whether level of education has any basis on the produced variants.

$\$ \quad$ highlighting the influence of the course of study on the variables.

$4 \quad$ examining the effect of speech pattern/style on the selected variants.

A good number of researches have been done on linguistic variable in relation with social variables. However, most of these works were done in native speakers' speech communities such as Labov (1972), Fasold, (1984), Trudgil (1986), etc. In Nigeria only a few scholars like Awonusi (1985, 2004), and Jibril (1986) have worked on sociolinguistic variables. This study captures the incidence of English phonology in our tertiary institutions across the basic linguistic groups using Quantitative Analysis. We also focus on what make English in our tertiary institutions to be different from other varieties of English and that of the native speakers. We equally examine how these variations correlate with some social factors such as social class, level of education, ethnicity, course of study, and style. The description of the segments and their correct realisation despite the variants will help and contribute immensely to linguistic theories in terms of linguistic universals, especially in the areas of phonological theories and rules, sociolinguistic theory, Second Language Acquisition (SLA), and Second Language Teaching and Learning (SLTL).

Sociolinguistic as a field of study is multidisciplinary as it relates the use of language to the society, (Milroy \& Milroy 1992). The scope of study covers some selected social variables ( social class, level of education, course of study and style) and two phonological variables $/ \theta /$ and $/ 2 /$ which occur on the same word like,' thirty' as tested on the population of study. A total number of sixty students were used, representing twenty from each institution. The population was selected through random sampling in each school comprising 10 males and 10 females. As Nigerian tertiary system is basically a four year program system except in few courses, 5 students were selected from each level. Although a larger population would have been ideal, it is believed this number is adequate as a larger number would render the analysis rather cumbersome. 


\section{Theoretical Framework and Research Methodology}

The complex nature of human language has brought up several theories in the second language usage. Linguistic variables are distributed according to sociolinguistic markers and this has existed from time immemorial in every language as can be seen on the Linguistic Shibboleth in Judges 12:4-6, (King James Version, KJV).

"...then said they unto him, say now 'Shibboleth": $\left[\int_{I}\right.$ bole $\left.\theta\right]$ : and he said, [sibolet] for he could not frame to pronounce it right. Then they took him, and slew him at the passages of Jordan, and there fell at that time of the Ephraimites forty and two thousand".

In Nigeria during the civil war, the same was used in identifying the opposing warring elements through their pronunciation of words like $/$ toro $/ \sim$ [tro] (a former Nigerian currency denomination and equivalent of three pence), and $/ \mathrm{SISI}_{\mathrm{I}} \sim\left[\int_{\mathrm{I}} \int_{\mathrm{I}}\right]$ (a former Nigerian six pence or farthing). These differences in the pronunciation of the same token could be attributed to some social factors. Milroy (1982: 143) argues that the strongest vernacular speakers however appeared rather consistently to be those whose local network ties were strongest. It is on these bases, that we find it necessary to adopt 'Accommodation Theory' (1991) by Giles and Coupland as our 'Theoretical Frame'. This theory focuses on the interactive aspect of communication and highlights its negotiative nature, which make people to converge or diverge. In sociolinguistics, understanding a language in society means that one has to understand the social network in which the language is embedded.

The Labovian Quantitative Model (1972: 181) is adopted as our theoretical approach. This model has been used for a number of studies with an appreciable success. This method involves the acquisition of information from the society and the treatment of data using mathematical and scientific technique. Labov believes that if our observations are to be valid, we must not just describe data from our introspection, but from the society. He is of the opinion that linguists must describe performance in order to understand language as used by the people and the people must cover all classes. This method helps the researcher to arrive at vernacular forms. The approach believes much on native speakers' intuition and judgment (Labov 1975: 31). The investigation focuses on predetermined lists of linguistic variables, which are elements known in advance to have different realizations, such as $[\mathrm{h}] /[\varnothing]$. For each variable there is a list of its variants. Sociolinguists argue that language exists in context, dependent on the speaker who is using it and dependent on where it is being used and why. Speakers mark their personal history and identity in their speech as well as their sociocultural, economic and geographical coordinates in time and space. Indeed, some researchers would argue that, since speech is obviously social, to study it without reference to society would be like studying courtship behaviour without relating the behaviour of one partner to that of the other.

\section{Data Elicitation}

Data are elicited through the use of questionnaires to get personal information from the respondents. Word lists and micro-tape were used for recording of data directly as uttered by the respondents. The researcher also interacted with the informants in formal and informal settings like lecture halls, seminar rooms, students' forum, departmental/college week, sport arena and in the eateries. Groups, individual discussions and interviews were carried out. Supplementary recording were done at different social contexts. The tested items comprise word lists and sentences that have the variants to be tested. The variants are subjected to phonetics and phonological transcription immediately or thereafter.

Since urban sociolinguistics is corrrelational (Romaine 1990: 165), it follows that we should have some means of sampling, collecting and analyzing two kinds of variables. The simple stratified random sampling method is used in selecting the population of the study, so that it would be representative enough, though no pre-test was carried out. The entire students' population is stratified into three cells: Redeemer's University (RUN) a privately owned University, University of Lagos (UNILAG), a federal government owned institution, and Lagos State University, (LASU), a state government school. In each cell, random sampling is used in selecting our informants as we cannot cover the entire population considering time and other constraints. This also helped in obtaining qualitative sociolinguistic data of the students' spoken English as used in these speech communities. Table 1 shows a breakdown of the number of students selected from each speech community. 
Table 1. Number of Respondents from Selected Institutions

\begin{tabular}{lc}
\hline Name of Institutions & Number of Respondents \\
Redeemer's University (RUN) & 20 \\
University of Lagos (UNILAG) & 20 \\
Lagos State University (LASU) & 20 \\
$\quad$ Total & $\mathbf{6 0}$ \\
\hline
\end{tabular}

Source: Researcher's Field Survey, 2011

Below are some of the characteristics of the samples of the informants. The informants were selected in such a way as to allow for a good representation of each of our chosen social parameters.

Table 2a-c. Classification of Informants

2a: Classification by Socio-Economic Class

\begin{tabular}{lc}
\hline Class & number \\
Upper class & 20 \\
Middle class & 20 \\
Lower class & 20 \\
Total & $\mathbf{6 0}$ \\
\hline
\end{tabular}

Source: Researcher's Field Survey, 2011

2b. Classification by Level of Education

\begin{tabular}{cc}
\hline Levels & number \\
100 & 15 \\
200 & 15 \\
300 & 15 \\
400 & 15 \\
Total & $\mathbf{6 0}$ \\
\hline
\end{tabular}

Source: Researcher's Field Survey, 2011

2c. Classification by Students' Disciplines

\begin{tabular}{cc}
\hline Colleges/Faculty & number \\
Humanities/ Arts & 20 \\
Sciences & 20 \\
Engineering & 20 \\
Total & $\mathbf{6 0}$ \\
\hline
\end{tabular}

Source: Researcher's Field Survey, 2011

In order to quantify our data, index and scale of value were worked out for each variant. The division of the variants was based on the principle of assumed knowledge of the social prestige attached to the variants. When the ranking of the variants was complete, each occurrence of the variable was recorded in two different styles for each informant. For instance an informant may have his scores in one speech as shown below for variable / $\theta /$ :

a) Value of Variants

$$
\begin{array}{ll}
/ \theta / & -1 \\
/ \theta / & -2 \\
/ \theta / & -3
\end{array}
$$

\section{Phonetic Variants}

$$
\begin{aligned}
& / \theta / \\
& / \mathrm{t} / \\
& / \mathrm{d} /
\end{aligned}
$$

b) Calculation of Scores
8 instances of
1 instance of
1 instance of
Total

$$
\begin{array}{ll}
/ \theta /, & 8 \times 1=8 \\
/ \mathrm{t} / . & 1 \times 2=2 \\
/ \mathrm{d} / & 1 \times 3=3 \\
\hline
\end{array}
$$
Average Score 


\section{c) Calculation of Index}

$$
(1.3-1.0) \times 100=30
$$

\section{Data Analysis and Findings}

The main objective of this study is to investigate the co-variance of linguistic (phonology) and sociological variables. In order to measure this kind of correlation, we first had to take records of each variable in the three contextual styles for individual informant. Index scores for each informant were then developed and the index score for each sociological parameter was calculated. By means of these scores, we were able to give answers to our research questions and our findings as represented below:

\subsection{Patterns of Variation in $/ \theta / \& / \partial /$}

$/ \theta /$ is a voiceless dental fricative as in $/ \theta ə: t \mathrm{l} /$ 'thirty', but some Nigerian speakers of English realize it a voiceless alveolar plosive [t] for example [ta:ti] 'thirty'. There is a total change in manner and place features. It is only phonation that the variants $/ \theta /$ and $[t]$ share in common, which is voiceless. Acoustically and articulatorily, these are two different phonemes, to some Nigerian speakers there is an overlapping as the two sounds are auditorily the same, and as such are used in free variation. The variants, as shown by our analysis are caused by social variables such as class, level of education, discipline/career and style.

/ə: / is a mid-high central vowel as in /wə:d/ 'word', but most Nigerian speakers of English derive it as a back low vowel as [wo:d] or mid-low front vowel in a word like 'bird' [bed] instead of /bə:d/. The major reason for this change is that most Nigerian languages lack this English vowel; as such many Nigerian speakers of English readily substitute it with closely related sounds in their languages.

\subsubsection{Social Class Differentiation}

Table 3. Index Scores by Class and Style

\begin{tabular}{lccc}
\hline Style & Lower Class & Class & \\
& 136 & Middle Class & Upper Class \\
Word List & 174 & 31 & 10 \\
Reading Style & 181 & 72 & 25 \\
Informal Style & 165 & 60 \\
\hline
\end{tabular}

Source: Researcher's Field Survey, 2011

Table 3 shows the average index score for the three social classes established in each of the three contextual styles: word list (WL), reading style (RS) and informal style (IS). Index scores are plotted along the abscissa. The lines on the graph connect scores obtained in each of the three social classes in the three speech styles. The information on table 3 is graphically represented in graph 1 below. The presentation shows that the $/ \theta /$ variable is a good class differentiation as it has established different social classes. These classes are reflected in their speech behaviour as in each style, the scores rise consistently from UC to LC. The variants by the UC are closer to prestige norm while that of LC are further away and that of MC stay in between. This pattern of variation confirms that the higher the social class the higher the use of the prestige forms. However, a cursory look at the graph indicates that the MC has a very steep gradient of ascent in between RS and IS. This corroborates Labov's claims that members of the middle class have greater consciousness of the social importance of linguistic variables. This he calls "linguistic insecurity" of the middle class, which is also the case in Nigeria.

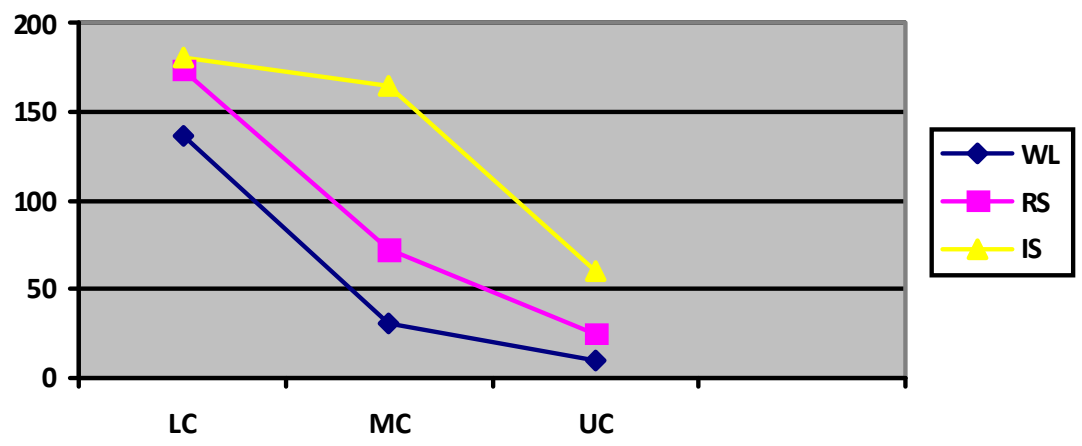

Figure 1. Variable $/ \theta$ / by Class and Style 


\subsubsection{Levelyn of Education}

Table 4. Index Scores by Level of Education and Style

\begin{tabular}{lllll}
\hline \multicolumn{1}{c}{ Style } & Levels & & \\
& $\mathbf{1 0 0}$ & $\mathbf{2 0 0}$ & $\mathbf{3 0 0}$ & $\mathbf{4 0 0}$ \\
Word List & 89 & 68 & 27 & 15 \\
Reading Style & 149 & 99 & 60 & 46 \\
Informal Style & 180 & 168 & 111 & 70 \\
\hline
\end{tabular}

Source: Researcher's Field Survey, 2011

The above table 4 shows that the level of educational attainment influences the sound articulation as well. The fresher's (who are the 100 level students) realization of / $/ \boldsymbol{\theta} /$ sound is not as sophisticated as those in other levels. The perfection in articulation progresses positively in relation to the level of education. This is evident in the fact that those at 400/500 level have attained a near native speaker realization than those in other levels as shown in calculation of index table and on the graph below, though not in every instances, because there were instances that the researcher tumbles into freshers who posses better realization of tokens than some final year students. This could be attributed to the informant's social background, exposure and the foundation in pre-tertiary schools.

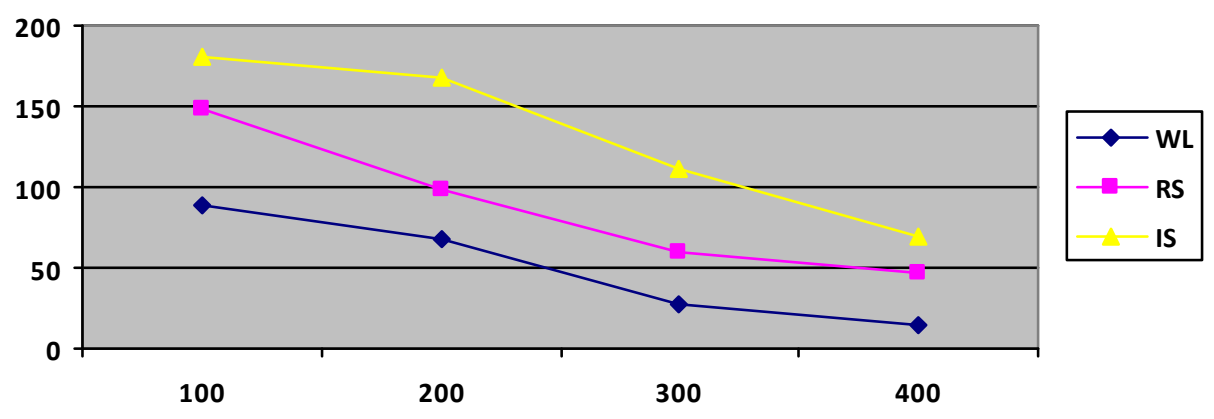

Figure 2. Variable / $\theta$ / by Level of Education

Table 5. Discipline/Career

\begin{tabular}{lccc}
\hline Style & \multicolumn{3}{c}{ DISCIPLINE } \\
& HUMANITIES & SCIENCES & ENGINEERING \\
Word List & 44 & 68 & 115 \\
Reading Style & 60 & 72 & 113 \\
Informal Style & 75 & 76 & 133 \\
\hline
\end{tabular}

Source: Researcher's Field Survey, 2011

The course of study has a great influence on the speaker's realization of the phoneme. It is observed generally that the informants whose field of study is language related is more conscious of sound articulation than those in other disciplines. This we observed, is of the fact that the student in the humanities offer more pronunciation courses like Spoken English, Phonetics and Phonology, Basic Speech drills, while those in other disciplines ended up in only the basic study skills offered at 100 level as a general course. 


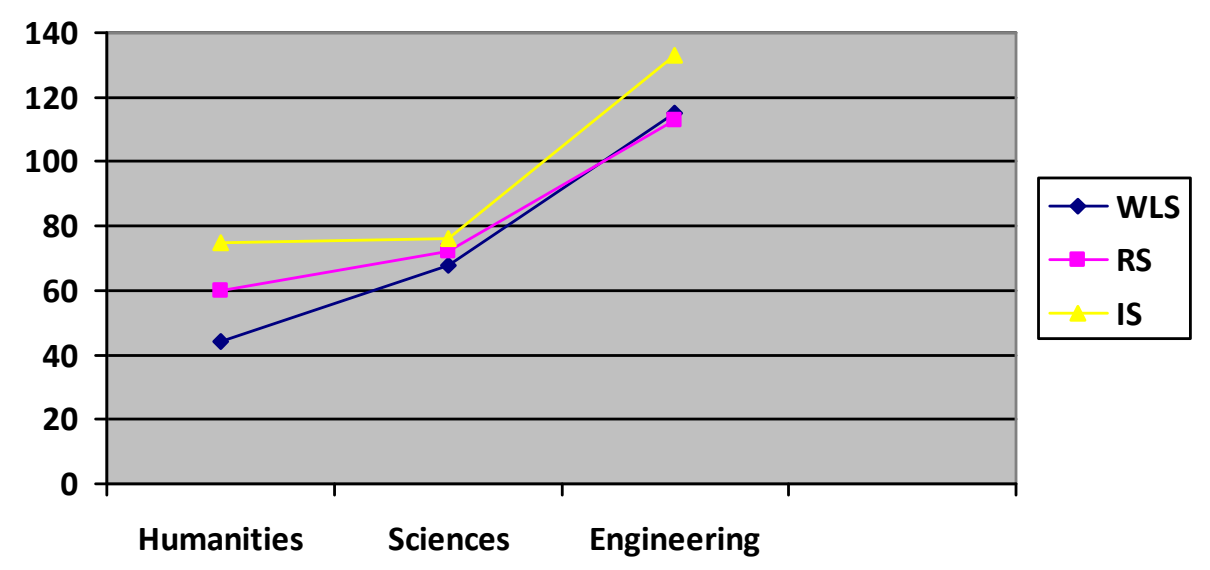

\subsection{Pattern of Variation in /3:/}

Figure 3. Variable / $\theta$ / by Discipline

Table 6. Index Scores by Class and Style

\begin{tabular}{lccc}
\hline Style & Lower Class & Class & \\
& Middle Class & Upper Class \\
Word List & 138 & 136 & 80 \\
Reading Style & 140 & 138 & 100 \\
Informal Style & 160 & 140 & 120 \\
\hline
\end{tabular}

Source: Researcher's Field Survey, 2011

This variable /3: / shows social class differentiation. The pattern of variation is similar to what was obtainable in $/ \theta /$. The higher the social class, the closer the approximation to the standard norm. However, the pattern does not show a marked stylistic variation, what we observed is that members of all classes use the lower prestige / $\mathrm{o} / /$. This trend is exhibited by a large spatial separation of the lines on the graph between the low index scores and the high index scores. The lines in the graph including the UC all have high index scores, even at the area of WLS. This shows that most university students are very far from the prestige norm in the variable, irrespective of the class or social background. However, those in the upper class were more conscious of their pronunciation in all style levels descending from WL to IS. This anomaly is traceable to the fact that the speakers indigenous languages do not have the English vowel $11 / 3:$ / and the closer sound to it, is the / $/$ :/ sound which is readily handy for substitution. The index score table for class and graph are presented in table 5 above and statistical representation in figure 4 below, respectively.

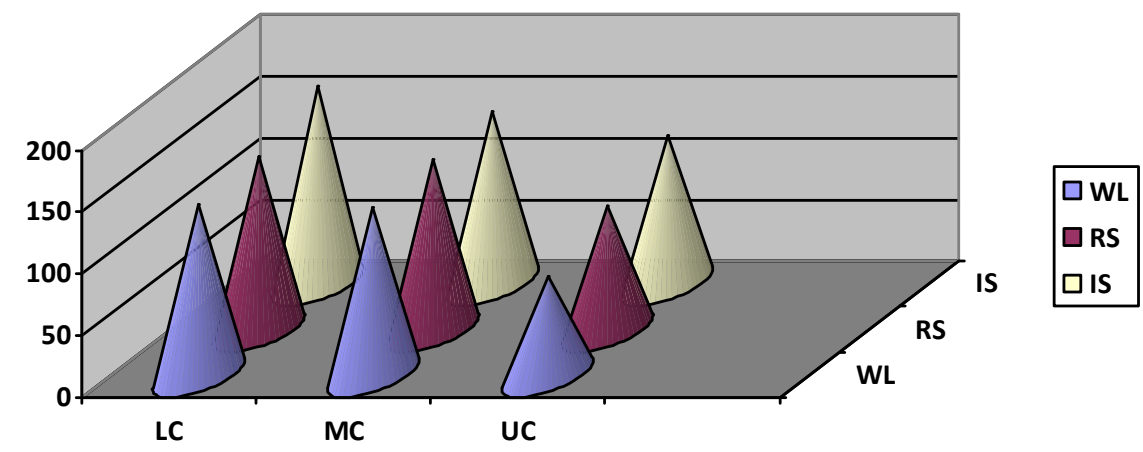

Figure 4. Variable / 3: / by Class and Style 
Table 7. Index Scores by Level of Education and Style

\begin{tabular}{cllll}
\hline \multicolumn{1}{c}{ Style } & $\mathbf{2 0 0} \mathbf{~ L e v e l s ~}$ & & \\
& $\mathbf{1 0 0}$ & $\mathbf{2 0 0} \mathbf{~ L}$ & $\mathbf{3 0 0} \mathbf{~ L}$ & $\mathbf{4 0 0} \mathbf{~ L}$ \\
Word List & 155 & 152 & 148 & 145 \\
Reading Style & 157 & 157 & 150 & 146 \\
Informal Style & 160 & 160 & 155 & 154 \\
\hline
\end{tabular}

Source: Researcher's Field Survey, 2011

The educational level influence did not have much impact on the realization of this sound as the sound proves difficult for the students to realize. The only difference is observable in the style where the informant fared better at WLS than in IS. They were better in WLS because they read from a list and they took time in pronouncing them whereas in IS they were talking unconsciously without taking cognizance that their speech were recorded.

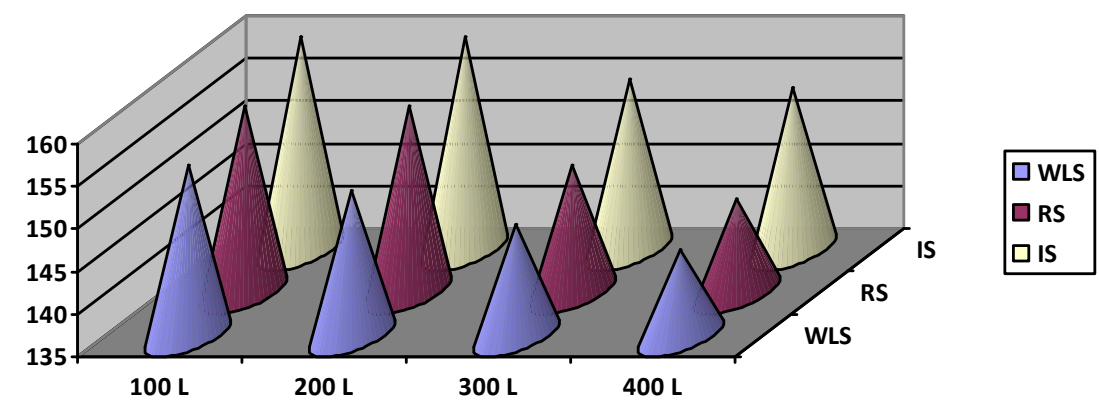

Figure 5. Variable / 3: / by Level of Education

Table 8. Index Scores by Discipline and Style

\begin{tabular}{llcl}
\hline Style & DISCIPLINE & \\
& HUMANITIES & SCIENCES & ENGINEERING \\
Word List & 130 & 140 & 143 \\
Reading Style & 147 & 150 & 150 \\
Informal Style & 150 & 152 & 160 \\
\hline
\end{tabular}

Source: Researcher's Field Survey, 2011

Though the deviant realization was high in all discipline it ascends from the humanities to the Engineering. This is proof those that study language related courses were still able to realize better form than those in other fields.

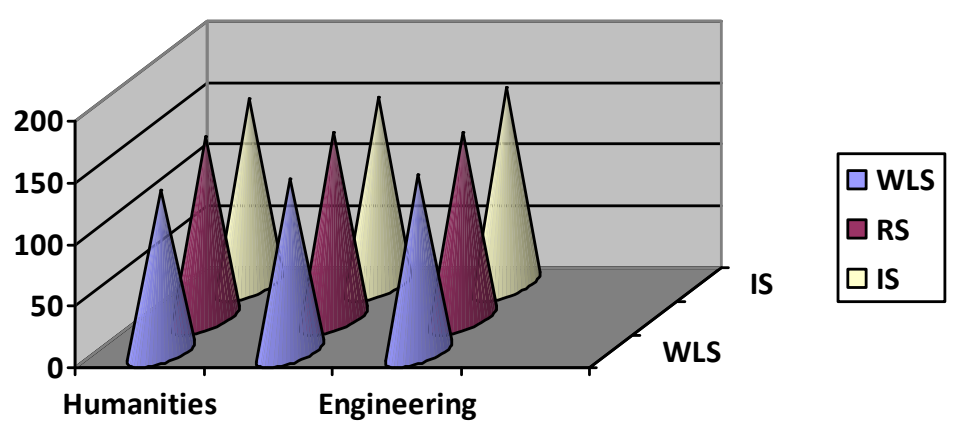

Figure 6. Variable / 3: / by Discipline and Style 


\section{Conclusion and Recommendations}

On the bases of our findings we conclude that, there is there a correlation between the social class and the actual output of the variables realized. Secondly, there is covariation between the level of educational and the type of variant produced. In addition there is a relationship between the course of study of the speaker and the type of variant articulated. As such spoken English instructors in the Nigerian tertiary institutions should not place every learner on the same scale or subject them to the same conditions. The instructors have to recognise the different social factors in individual student and tackle them individually. By this, the student will learn better and perform well in spoken English which will invariably reflect on other courses as English is the only language of instruction in tertiary institutions in Nigeria.

The analysis of our data was basically from production perspective; it would be worthwhile if further research on ENTI is extended to cover laboratory or experimental testing of these sounds and some suprasegmentals.

\section{References}

Adetugbo, A. (1993). English Phonetics: A Course Text. Lagos: University of Lagos Press.

Akeredolu-Ale, B. I. (2005). Social Stratification and the Challenges of Second Language Acquisition: A Case Study of Selected Yoruba-English Bilinguals in Ogun State, Nigeria. English Language Teaching Today, $4(2), 8-15$.

Awonusi, V. O. (2004). The English Language in a 'Global Context'. In A. B. K Dadzie, \& Segun Awonusi (eds), Nigerian English: Influence and Characteristics. Lagos: Concept Publication.

Babalola, E. A., \& Awonusi, S. (2004). (eds). The Domestication of English Language in Nigeria: A Festschrift in Honour of Abiodun Adetugbo. Lagos: University of Lagos Press.

Banjo, Ayo. (1995). Towards a Definition of Standard Nigerian English. In Actes du Congres de La Societe Lingustique de L'Afrique Occidentale, Abidjan.

Coupland, N., Sarangi, S., \& Candlin, C. N. (2001). (eds). Sociolinguistics and Social Theory. England: Longman.

Eka, D. (1993). Timing in Educated Spoken Nigerian English. Journal of Humanities, 3, 1-11.

Fasold, R. (1984). The Sociolinguistics of Society. England: Basil Blackwell Publishers Ltd.

Giles, H., \& Coupland, N. (1991). Language, Contexts and Consequences. Keynes: Open University Press.

Hudson, R. A. (1996). Sociolinguistics. U.S.A: Cambridge University Press.

Jibril, M. (1986). Sociolinguistic Variation in Nigerian English. English World-wide, 7, 47-75. http://dx.doi.org/10.1075/eww.7.1.04jib

Kachru, B. (1983). Models for Non-Native English. In Kachru B.B. (ed), The Other Tongue: English Across Cultures (pp. 31-57).

Labov, W. (1972a). Sociolinguistic Patterns. Oxford: Blackwell.

Labov, W. (1994). Principles of Linguistic Change (Vol. 1): Internal Factors. Oxford: Basil Blackwell. pp. 12-34 .

Le-Page, R., \& Tabourt-Keller, A. (1985). Acts of Identity: Creole-Based Approaches to Language and Ethnicity. Cambridge: Cambridge University Press.

Linguistic Variation. Retrieved from http://www.valdosta.edu/ jlcampbe/linguistic variation.htm

Mill, C. W. (1959). The Sociological Imagination. New York: Oxford University Press.

Milroy, L., \& Milroy, J. (1992). Social Network and Social Class: Towards an integrated Sociolinguisticmmodel. Language in Society, 21, 1-26. http://dx.doi.org/10.1017/S0047404500015013

Petyt, M. (1978). Secondary Contraction in West Yorkshire Negatives. In Trudgill, P. (ed), Sociolinguistic Patterns of British English. London: Edward Arnold Pub. Ltd.

Regional and Social Variation variable - a characteristic shared to differing degrees by individuals in a population. Retrieved from http://www.ac.wwu.edu/ sngynan/slx6.html

Romaine, S. (2003). Language in Society. New York: Oxford University Press.

Russel, J. (1982). Social Network and Linguistic Focussing. In Suzanne Romaine (ed), Sociolinguistic Variation. London: Edward Arnold Pub. Ltd. 
Sociolinguistics. Retrieved from http://www.en.wikipedia.org/wiki/Sociolinguistics

The Holy Bible. (1974). King James Version. Texas: International Bible Association.

Trudgill, P. (1986). Dialect in Contact. Oxford: Basil Blackwell.

Udofot, I. (2004). In Segun Awonusi, \& E. A. (ed), Varieties of Spoken Nigerian English. 